\title{
KEPRIBADIAN TOKOH DALAM CERPEN RUSMI INGIN PULANG KARYA AHMAD TOHARI
}

\author{
Leli Nisfi Setiana
}

PBSI FKIP Unissula

Surel: lelinisfi@unissula.ac.id

\begin{abstract}
Abstrak
Tujuan dalam penelitian ini adalah mendeskripsikan bentuk kepribadian tokoh dalam cerpen Rusmi Ingin Pulang. Permasalahan dalam penelitian ini adalah bagaimana bentuk kepribadian tokoh dalam cerpen Rusmi Ingin Pulang karya Ahmad Tohari. Pendekatan yang digunakan dalam penelitian cerpen Rusmi Ingin Pulang adalah pendekatan objektif psikologi sastra. Pendekatan objektif ini membatasi diri pada penelaahan karya sastra itu sendiri, terlepas dari unsur ekstrinsik yaitu pengarang dan pembaca. Berdasarkan hasil penelitian yang dilakukan oleh peneliti diperoleh sebanyak 19 data dari tujuh kategori kepribadian tokoh dalam cerpen Rusmi Ingin Pulang yaitu Gapasioneerdern (orang hebat), Cholerici (orang gerang), Sentimentil (orang perayu), Nerveuzan (orang penggagup), Flagmaciti (orang tenang), Sanguinci (orang kekanak-kanakan), dan Amorfem (orang tak berbentuk).
\end{abstract}

Kata kunci: Kepribadian tokoh, cerpen Rusmi Ingin Pulang.

\section{Abstract}

The purpose of this study is to describe the personality forms of the characters in the short story Rusmi Want to Go Home. The problem in this research is how the personality of the character in the short story of Rusmi Want to Go Home by Ahmad Tohari The approach used in the short story research Rusmi Want to Return here is an objective approach to literary psychology. This objective approach limits itself to the study of literary work itself, apart from the extrinsic element that is the author and the reader. Based on the results of research conducted by researchers obtained as imany as 19 , data from seven personality categories in the short story Rusmi Want to Go Home namely Gapasioneerdern (great people), Cholerici (loud people), Sentimental (seducers), Nerveuzan (people who are nervous), Flagmaciti (calm people), Sanguinci (childish person), and Amorphem (formless person).

Keywords: Personality figures, short stories Rusmi Want to Go Home. 


\section{PENDAHULUAN}

Fenomena munculnya sebuah imajinasi dan kreativitas karya sastra dapat terjadi pada sebuah lingkungan masyarakat pengarangnya atau sekitar lingkungan pengarang. Pada saat ini sastra modern dikenal dengan bermacam-macam bentuk karya sastra, misalnya puisi, cerita pendek, novel dan lainnya. Dalam karya sastra tersebut bukan berisi tentang pengalaman sejati, melainkan rekaan atau dunia imajinasi pengarang (Noor, 2007:2). Penelitian dan analisis terhadap suatu karya sastra terkandung maksud untuk mendeskripsikan terjadinya sebuah cerita. Pendekatan yang digunakan untuk menganalisis suatu karya sastra harapannya dapat disesuaikan dengan bidang dan kajiannya. Noor menjelaskan lebih lanjut lagi bahwa dalam penelitian sastra sangat dibutuhkan bantuanbantuan ilmu lain yang relevan, lebihlebih dalam interpretasi karya sastra. Kemudian untuk menginterpretasi karya sastra dalam bentuk cerpen yang terpenting adalah pendekatannya yaitu pendekatan segi intrinsik, sebab pendekatan atau penilaian terhadap karya sastra sering pula bergantung pada interpretasi. Ilmu-ilmu bantu yang lain yang dimaksud adalah ilmu yang ada hubungannya dengan ilmu sastra, yang diantaranya yaitu psikologi (ilmu jiwa). Ilmu bantu tersebut sangat besar peranan dan manfaatnya dalam aspek penelitian karya sastra. Untuk meneliti aspek psikologi maka dalam suatu karya sastra (novel) pendekatan yang digunakan adalah pendekatan ekstrinsik.

Semi (1989:46) mengatakan, bahwa modernisasi pada sebuah masyarakat dapat ditandai dengan penguasaan sikap kejiwaaan yang baik akan mendorong perkembangan dan kemajuaan serta penguasaan dalam segi material dan segi rohaniah, pada sebuah masyarakat modern. Aspek pengajaran menjadi hal penting dalam kegiatan pengajaran sastra, yang meliputi aspek kognitif, afektif dan psikomotor meskipun ketiganya memiliki perbedaan namun berkaitan erat satu dengan lainnya. Tujuan penelitian ini ialah mendeskrisikan aspek kepribadian tokoh utama pada cerpen Rusmi Ingin Pulang. Berdasarkan penggambaran di atas, peneliti melakukan penelitian dengan judul Aspek Kepribadian Tokoh Utama pada Cerpen "Rusmi Ingin Pulang" dalam karya Ahmad Tohari.

Mengacu pada latar belakang di atas, penulis mengangkat rumusan Bahasalah yastra bagaimana dimensi kepribadian pada tokoh utama dalam cerpen Rusmi Ingin Pulang karya Ahmad Tohari

\section{Teori Kepribadian Psikoanalisis Sigmund Freud}

Menurut Hartoko dalam Noor (2007:93), penelitian psikologis dilakukan dengan metode mendes- 
kripsikan dan penafsiran antara teks sastra dengan psikoanalisis dalam bentuk ucapan (imajinasi) dan ungkapan bahasa seseorang dalam teks sastra dengan menggunakan teori psikologis ala Freud.

Pengembangan teori kepribadian berkaitan dengan pemahaman yang dipengaruhi oleh paradigma teori psikologi kepribadian. Penggambaran wujud dari teori kepribadian adalah bersifat daeskriptif dan mudah dipahami.

Pemahaman ranah kajian psikologi meliputi pikiran, kegiatan dan perasaan manusia yang diaplikasikan secara rasional, psikologi, sistemik, dan metode. Dalam teori psikologi lebih menitikberatkan spesifik suatu individu. Alwisol (2009:1-2). Secara ideal, teori harus mengandung sekumpulan asumsi relevan yang secara sistematis saling berkaitan dan membentuk definisi empiris. Begitu juga pada teori kepribadian yang didefinisikan berdasarkan konsepkonsep khusus yang terkandung dalam teori tertentu yang dianggap memadai untuk mendeskripsikan latau memahami tingkah laku manusia secara lengkap dan utuh. Istilah kepribadian dalam bahasa popular ditujukkan sebagai ciri-ciri watak seseorang secara konsisten berupa identitas khusus suatu individu

Dalam bahasa populer, istilah kepribadian juga ciri-ciri watak seorang individu yang konsisten, yang memberikan kepadanya suatu identitas sebagai individu yang khusus (Kurniawati, 2003:1).

Kualitas kejiwaan manusia meliputi tiga hal yang utama yaitu emosionitas, proses pengiring, dan aktivitas. Heymans dalam Sobur (2009:317) berdasarkan lemahnya ketiga unsur dalam kejiwaan manusia menjadi tujuh, yaitu: unsur Gapasioneerdern atau orang hebat, Cholerici atau orang gerang, Sentimentil atau orang perayu, Nerveuzan atau orang penggagup, Flagmaciti atau orang tenang, Sanguinci atau orang kekanak-kanakan, dan Amorfem atau orang tidak berbentuk. Berdasarkan penjelasan tersebut diperoleh kesimpulan bahwa kualitas kejiwaan dipengaruhi oleh tiga hal utama lalu diturunkan menjadi tujuh kriteria.

\section{Pendekatan Psikologi Sastra}

Psikologi berasal dari kata Yunani psyche, yang berarti jiwa, dan logos yang berarti ilmu. Psikologi mengandung maksud ilmu jiwa yang menyelidiki dan mempelajari tindakan manusia. Asal dari ilmu Psikologi dari kata Yunani yaitu psyche adalah jiwa dan qogos adalah ilmu. Menurut Atkinson dalam Minderop (2010:3) mengungkapkan bahwa psikologi adalah suatu ilmu jiwa yang secara khusus mengimplementasikan segala bentuk tingkah laku manusia. Sehingga dapat disimpulkan bahwa psikologi adalah implementasi tindakan manusia yang berasal dari perpaduan ilmu dan jiwa manusia. 
Ratna (2008:342) menjelaskan tujuan psikologi sastra ialah memahami aspek kejiwaan yang terdapat pada karya sastra. Jadi, Psikologi menurut Ratna adalah pemahaman kepada masyarakat seacra tidak langsung mengenai tokoh dan aspek permasalahan yang ada di dalamnya.

Analisis cerpen Rusmi Ingin Pulang fokus mengkaji dan memecahkan permasalahan psikologis kepribadian tokoh dalam cerita. Sumber data primer tinjauan psikologi sastra pada cerpen Rusmi Ingin Pulang dilakukan dengan pendekatan tekstual.

\section{METODE}

Jenis penelitian ini ialah penelitian kualitatif deskriptif berdasarkan pendekatan psikologi sastra dan kajiannya adalah karya sastra yang menekankan pada pendekatan psikologi sastra yang berkaitan erat dengan tiga gejala utama, yaitu pengarang, karya sastra, dan pembaca (Ratna, 2008:342). Dengan kata lain pendekatan ini memandang dan menelaah sastra dari segi kepribadian tokoh utama yang membangun karya sastra. Dalam penelitian ini lebih ditekankan adalah kepribadian tokoh utama, karena yang akan dikaji adalah kepribadian tokoh utama ditinjau secara psikologis menggunakan teori Hymes.

Populasi data dalam penelitian ini berupa cerpen yang berjudul Rusmi Ingin Pulang karya Ahmad Tohari.
Terdapat pada halaman 107, tebal buku 1,2 cm, cetakan pertama, diterbitkan oleh PT Gramedia, Pustaka Utama anggota IKAPI, Jakarta. Sampul muka berwarna kuning dengan tulisan judul berwarna hitam, nama Ahmad Tohari berwarna hitam. Adapun data-data berupa kutipan cerpen yang berkaitan dengan kepribadian tokoh utama dalam cerita. Sampel pada penelitian ini adalah kutipan kalimat dan paragraf dalam wacana cerpen.

Teknik pencatatan adalah teknik yang diakukan pada penelitian ini. Langkah-langkah yang perlu dilakukan dalam teknik pencatatan sebagai berikut.

a. Membaca dengan teliti cerpen Rusmi Ingin Pulang karya Ahmad Tohari secara berulang-ulang,

b. Membaca buku, hasil penelitian, dan jurnal yang relevan.

c. Mencatat kutipan cerpen yang berkaitan dengan kepribadian tokoh utama dalam cerpen Rusmi Ingin Pulang karya Ahmad Tohari.

Melalui penelitian dan pengemBahaisa, Sastro
bangan ini, peneliti berusaha untuk mengembangkan produk yang layak dan efektif digunakan dalam pembelajaran. Produk yang dikembangkan pada penelitian ini adalah media pembelajaran interaktif berbasis $e$ learning materi Kepribadian Manusia.

Jenis penelitian ini yang digunakan ialah penelitian kualitatif. Data 
yang dihasilkan berupa ucapan, tulisan serta prilaku seseorang pada kutipan dalam cerpen Rusmi Ingin Pulang karya Ahmad Tohari. Sedangkan teknik interpretasi digunakan dalam penelitian ini sebagai teknik analisis pada kutipan dalam cerpen.

Semi (2012:31-32) mengungkapkan tiga hal utama dalam melakukan teknik analisis yaitu pendeskripsian bagian penting dalam penelitian, merumuskan hasil penelitian serta simpulan dalam bentuk tertulis.

Langkah-langkah dalam melakukan analisis data penelitian sebagai berikut:

1. Menggolongkan kepribadian tokoh utama yang terdapat dalam cerpen Rusmi Ingin Pulang karya Ahmad Tohari.

2. Menafsirkan kesimpulan penelitian.

3. Menarik kesimpulan.

\section{HASIL DAN PEMBAHASAN}

Hasil penelitian dan pembahasan analisis tipe kepribadian manusia pada cerpen Rusmi Ingin Pulang karya Ahmad Tohari berdasarkan tujuh tipe kepribadian menurut Heymans sebagaimana dijelaskan dalam hasil analisis pada parafrase kutipan cerpen sebagai berikut.

\section{Gapasioneerden (Orang Hebat)}

"Kang Hamim," kata Pak RT "Pagi buta kau berkunjung? Adakah permasalahan yang terjadi?" (RIP, 2015:109).
Berdasarkan kutipan dialog di atas, dapat kita analisis bahwa tokoh Pak RT mempunyai tipe kepribadian Gapasioneerden (orang hebat), yakni kepribadian seseorang yang memiliki rasa kekeluargaan yang kuat dan suka menolong orang yang lemah. Hal ini ditunjukan pada dialog Ada masalah penting? Yang diungkapkan Pak RT pada Kang Hamim. Dialog tersebut menjadi ciri dari kepribadian Pak RT. Karena pada dialog tersebut mengandung dua makna yang bersamaan. Yaitu makna rasa iba dengan rasa kekeluargaan dan mencoba menawarkan bantuan pada Kang Hamim.

"Demikiakah masalah itu hingga kamu datang ke saya?" tanya Pak RT. Kang Hamim keningnya berkerut (RIP, 2015:110).

Pada kutipan dialog di atas Pak RT secara tidak langsung menunjukan tipe kepribadian Gapasioneerden (orang hebat) pada Kang Hamim dengan mencoba bertanya tentang masalah yang sedang dihadapi oleh Kang Hamim. Dialog tersebut sangat jelas dan gamblang menunjukan rasa kekeluargaan Pak RT. Yaitu dengan mengajakakrdbicara dan bermusyawarah pada Kang Hamim. Karena dengan musyawarah tersebut, Kang Hamim akan terbuka dan bisa menceritakan masalahnya pada Pak RT.

"Sekarang saya paham tentang isi perasaanmu" (RIP, 2015:113).

Pada kutipan dialog di atas juga menunjukan akan rasa kekeluargaan 
Pak RT pada Kang Hamim. Ditunjukan dengan dialog apa yang sedang kamu rasakan. Dalam dialog ini, Pak RT menunjukan rasa empatinya pada Kang Hamim. Pak RT seakan-akan bisa merasakan masalah yang sedang Kang Hamim alami. Perasaan tersebut bisa membangun sebuah dialog yang penuh dengan kekeluargaan. Kang Hamim akan merasa terhibur dengan dialog Pak RT, karena merasa masih ada orang yang bisa diajak curhat selain seorang istri.

Pak RT tersenyum dan dalam hati ingin menenangkan tamunya. "Kang Hamim. Dalam rapat warga yang lalu, permasalahan ini akan disampaikan dan didiskusikan bersama warga. Intinya akan saya sampaikan bahwa menghalangi hak seseorang adalah perbuatan yang salah, anakmu memiliki hak dan dijamin saat pulang ke rumahmu." (RIP, 2015:113)

Pada kutipan dialog di atas menunjukan rasa suka menolong Pak RT kepada orang yang lemah seperti Kang Hamim yang sedang mengalami masalah. Dialog tersebut Pak RT mencoba memecahkan masalah Kang Hamim dengan menggunakan Pcara musyawarah secara kekeluargaan dengan masyarakatnya. Pak RT yang statusnya sebagai pemimpin desanya berharap cara ini bisa menolong Kang Hamim menyelesaikan masalahnya.

"Saya tidak percaya orang-orang disini dapat setega itu kepada Rusmi. Percayalah, warga dapat diatur sehingga mereka menerima Rusmi kembali ke Desa." (RIP, 2015:112)
Kutipan dialog di atas merupakan upaya yang dilakukan Pak RT untuk menyakinkan Kang Hamim supaya tidak bersikap pesimis. Selain itu, dialog tersebut juga menunjukan tanggung jawab Pak RT untuk membantu menyelesaikan masalah Kang Hamim.

"Percayalah kang, saya ketua $R T$ saya akan melindungi hak Rusmi sebagai warga disini, akan tetapi butuh waktu untuk merubah sikap masyarakat kepada Rusmi. (RIP, 2015:112)

Pada kutipan dialog di atas menunjukan akan kepatriotan yang baik Pak RT pada rakyatnya. Dia dengan optimis bisa memecahkan masalag yang dihadapi oleh rakyatnya.

\section{Flegmatici (Orang Tenang)}

"Semalam saya memang kurang tidur karena menghadapi permasalahan ini. Oleh karena itu, saya kemari." (RIP, 2015:110).

Pada kutipan dialog di atas menunjukan akan ketenangan Kang Hamim dalam menyikapi masalah yang sedang dihadapi. Kang Hamim dengan tepat memilih orang untuk diajak menyelesaikan masalahnya.

"Secara pribadi masalah ini sangat menggelisahkan. Sehingga saya mohon Pak RT dapat membantu menyelesaikannya." (RIP, 2015:110).

Pada kutipan dialog di atas menunjukan sikap tidak putus asa Kang Hamim. Walaupun masalahnya sulit untuk dipecahkan, Kang Hamim berusaha untuk tidak putus asa. Dia 
mencari seseorang yang bisa membantunya.

"Tidak ada cerita lain, selain bahwa Rusmi berkata bahwa Minggu depan mau pulangke rumah. Itulah yang mau saya itanyakan dulu, apa Pak RT dan warga setuju Rusmi pulang kemari?" (RIP, 2015: ...).

Dialog tersebut menunjukan sikap tenang Kang Hamim. Dia tetap tenang menyelesaikan masalahnya. Dia tidak egois dalam mengambil keputusan untuk menyelsaikan masalahnya. Dia tetap menghormati orang yang lebih pantas untuk memutuskan tindakanya.

\section{Sentimentil (Orang Perayu)}

"Bagaimana kalau ditolah oleh semua warga? Banyak warga yang menolak? Mereka tak ingin ada manusia kotor tinggal di sini dan akan demo menolak Rusmi pulang." (RIP, 2015:112)

Pada dialog di atas menunjukan sikap sentimentil Kang Hamim. Dia meluapkan emosinya untuk menjelaskan fakta yang ada di desanya. Dia juga memunculkan sikap impulsif.

"Pak RT benar. Tetapi ingatkah Pak RT dengan kejadian tertangkapnya copet di pasar satu bulan yang lalu. Hampir saja copet itu dibakar oleh pemuda di kampung. Saya takut alau kejadian itu akan menimpa pada anak saya karena selama ini dianggap sebagai aib dan menjadi kegelisahan bagi isteri saya sampai sering menangis di malam hari?" (RIP, 2015:112)

Dialog kutipan tersebut menunjukan sikap sentientil Kang Hamim ditujukan dengan pandai berbicara. Dia dengan lancar menjelasakan kasus yang hampir sama untuk dianalogikan dengan kasus putrinya. Dia bermaksud untuk membujuk Pak RT untuk bisa menyikap masalahnya dengan detail dan teliti. Mengenai dampak setelah keputusanya dibuat.

\section{Nerveuzen (Orang Penggugup)}

"Bagaimana jika sebenarnya mereka menolak Rusmi tetapi berpura-pura tetap menerima kedatangannya di kampung ini? Ini sama saja tetap akan menyiksa keluarga kami." (RIP, 2015:113).

Pada dialog di atas menunjukan sikap nerveuzen Kang Hamim. Walaupun Pak RT sudah menjamin masalahnya akan selesai, tetapi Kang Hamim masih saja protes dengan beberapa alasan yang ada. Selain itu, Kang Hamim juga terlalu agresif menanggapi masalahnya sampaisampai memikirkan berbagai kemungkinan yang akan terjadi. Walaupun demikian, Kang Hamim bukan tipe orang pendedam. Dia hanya ingin masalahnya bisa selesai tanpa ada dampak yang terjadi setelahnya.

\section{Cholerici (orang gerang)}

Rusmi dipandang sebagai aib oleh seisi kampung, sehingga ditolak oleh warga di kampungnya. Bahkan banyak pula pemuda di kampung yang menolak dengan tegas kepulangan Rusmi. (RIP, 2015:111)

Kutipan dialog di atas menyatakan sikap gerang warga kampung yang menganggap Rusmi sebagai aib bagi seisi kampung, sehingga mereka bersepakat untuk menolak kedatangan 
dan mengusir Rusmi jika kembali ke kampung.

"Masih ingat kan Pak RT, sebulan yang lalu ada copet yang ditangkap dan hampir dibakar oleh masyarakat kampong. Demikian itu yang membuat saya takut jika hal tersebut terjadi pada Rusmi yang selama ini oleh warga kampong sebagai aib. ”(RIP,2015:112)

Kutipan dialog di atas meyatakan sikap gerang kang Hamim terhadap pemuda warga kampung atas kejadian pencopetan yang terjadi di pasar. Kang Hamim menyampaikan cerita tersebut kepada Pak RT sebab dia merasa takut kalau anaknya si Rusmi kelak jika kembali ke kampung akan diperlakukan hal yang sama karena kabar burung bahwa Rusmi sejak bekerja di kota lalu Rusmi dianggap sebagai aib di kampung.

\section{Sanguinci (Orang Kekanak- kanakan)}

"Maka saya selalu gelisah. Istri saya malah sering menangis di malam hari. Begitulah, Pak. Jadi sekarang saya sekeluarga harus bagaimana?" (RIP, 2015:112).

Penggalan pada kutipan cerpen tersebut menyatakan isteri kang Hamim yaitu ibunda Rusmi yang kekanak-kanakan hinga menangis di malam hari karena kepikiran cerita copet yang tertangkap dan hampir dibakar di pasar. Hal tersebut menjadikan isteri kang Hamim resah dan terus menangis tidak jelas setiap malam memikirkan anaknya. Padahal kejadian tersebut belum tentu akan terjadi pada Rusmi, akan tetapi isteri kang Hamim selalu menangis seriap malam.

\section{Amorfem (Orang tak Berbentuk)}

"Dalam berbagai kegiatan dan acara di kampung, Rusmi kerap menjadi buah bibir oleh warga kampung. Bahkan dalam kegiatan pengajian, menjadi bahan gunjingan. (RIP, 2015:112).

Penggalan kutipan di atas menyatakan orang yang tak berbentuk yaitu kabar burung dan berita miring tentang Rusmi yang bekerja di kota sebagai bahan perbincangan dalam kehidupan sosial di masyarakat.

Semakin lama Rusmi semakin menjadi bahan pergunjungan yang pekat, sehingga namanya kian terpuruk di mata masyarakat (RIP, 2015:111).

Kutipan dialog di atas menyatakan Rusmi sebagai orang yang tak berbentuk (nyata) ada di kampung akan tetapi kabar miring tentangnya berkembang dengan santer, sehingga nama baik Rusmi tercemar sebab dijadikan bahan pergunjingan dan pelecehan oleh warga di kampungnya.

\section{PENUTUP}

\section{Simpulan}

Kepribadian tokoh yang terdapat dalam cerpen Rusmi Ingin Pulang karya Ahmad Tohani, diterapkan melalui tiga kategori yaitu 1) kategori kepribadian gapasioneerden, 2) kategori kepribadian flegmatici, 3) kategori sentimentil, 4) kategori nerveu- 
zen, 5) kategori cholerici, 6) kategori sanguinci dan 7) kategori amorfem.

\section{Saran}

Hasil penelitian dapat dijadikan sebagai referensi penelitian karya sastra selanjutnya serta menambah wawasan tentang dimensi kepribadian tokoh dalam cerpen Rusmi Ingin Pulang karya Ahmad Tohari.

\section{DAFTAR PUSTAKA}

Alwisol. 2009. Psikologi Kepribadian. Malang: UMM Pres.

Freud, Sigmund. 2009. Pengantar

Umum Psikoanalisis. Yogyakarta: Pustaka Pelajar.

Kurniawati, Heni. 2003. Psikologi Kepribadian. Purwokerto: Universitas Muhammadiyah Purwokerto.
Minderop, Albertine. 2010. Psikologi Sastra. Jakarta: Yayasan Pustaka Obor Indonesia.

Noor, Redyanto. 2007. Pengantar Pengkajian Sastra. Semarang: Fasindo.

Ratna, Nyoman Kutha. 2008. Teori Metode dan Teknik Penelitian Sastra. Yogyakarta: Pustaka Pelajar.

Tohari, Ahmad. 2004. Rusmi Ingin Pulang. Yogjakarta: Matahari.

Semi, Atar. 1989. Kritik Sastra. Bandung: Angkasa.

Semi, Atar. 2012. Metode Penelitian Sastra. Bandung: Angkasa.

Sobur, Allex. 2009. Psikologi Umum. Bandung: CV Pustaka Setia. 